УДК $347.1 ; 349.3$

DOI https://doi.org/10.32837/pyuv.v1i3(28).342

\author{
Ю. В. Кривенко \\ кандидат юридичних наук, доцент, \\ доиент кафедри иивільного права \\ Національного університету «Одеська юридична акаделія»
}

\title{
ВІЙСЬКОВОСЛУЖБОВЕЦЬ ТА ДОБРОВОЛЕЦЬ: ПРАВОВИЙ І СОЦІАЛЬНИЙ ЗАХИСТ
}

Одним 3 найважливіших напрямів військово-правової реформи в Україні є вирішення проблеми вдосконалення гарантій реалізації правового та соціального захисту військовослужбовців та добровольців. Це пов' язано з практичними питаннями, які виникають під час звернень до державних органів з питань правового та соціального захисту та потребують вдосконалення законодавства.

На актуальність дослідження впливає ситуація на Сході країни. Реформи в армії відбуваються в доволі непростий час. Досить важливим $€$ створення ефективної системи гарантій правового захисту захисників України, які перебувають на військовій службі або є учасниками добровольчих формувань. Посилення їх соціального захисту, зміцнення їх правового статусу повинно стати пріоритетним напрямом державної політики.

Конституційне регулювання соціального захисту військовослужбовців здійснюється на основі КонституціїУкраїни. Так, ст. 17 КонституціїУкраїни визначає гарантії соціального та правового захисту військовослужбовців: «Держава забезпечує соціальний захист громадян України, які перебувають на службі у Збройних силах України та в інших військових формуваннях, а також членів їх сімей» [1], однак поза увагою залишаються особи, що перебувають у складі добровольчих формувань.

Хоча норми Конституції України є нормами прямої дії, вони не можуть детально врегулювати всі аспекти соціального та правового захисту військовослужбовців. 3 огляду на це закріплені Конституцією України норми потребують додаткової конкретизації і розвитку в законах, указах Президента України, постановах Кабінету Міністрів України, наказах Міністерства оборони України та в інших нормативно-правових актах [2, с. 102110]. Особливо це стосується осіб, що перебувають у складі добровольчих формувань.

Міжнародно-правове регулювання правового та соціального захисту військовослужбовців також відіграє не останню роль в умовах ведення бойових дій на Сході України. Варто зазначити такі міжнародно-правові акти, як Женевська конвенція про поліпшення участі поранених і хворих у діючій армії, Женевська конвенція про поліпшення участі поранених, хворих та осіб, які зазнали корабельної аварії, із складу збройних сил на морі, Женевська конвенція про поводження 3 військовополоненими, Римський статут Міжнародного кримінального суду (прийнятий 17 липня 1998 р.) тощо. Ці міжнародно-правові акти містять правові норми, які визначають особливості забезпечення прав та соціального захисту військовослужбовців під час ведення бойових дій, надають їм право на застосування зброї, захищають їх життя і права під час перебування у полоні, а також визначають відповідальність за вчинення військових злочинів [3].

Об’єктом дослідження є визначення правового та соціального захисту військовослужбовців та осіб, що перебувають у складі добровольчих формувань.

Дослідженню визначення правового та соціального захисту військовослужбовців та осіб, що перебувають у складі добровольчих формувань, присвяченні праці українських та зарубіжних науковців, зокрема B.I. Борисової, О.В. Дзери, А.С. Довгерта, I.М. Кучеренко, В.В. Луця, В.Д. Примака, З.В. Ромовської, І.В. Спасибо-Фатєєвої, Є.О. Харитонова, Я.М. Шевченко. Здебільшого вченими аналізується цивільно-правовий захист фізичних осіб, а питання щодо визначення особливостей правового та соціального захисту військовослужбовців та осіб, що перебувають у складі добровольчих формувань, потребують додаткового вивчення та розробки. Гарантії соціального і правового захисту військовослужбовців та членів їх сімей передбачають, що військовослужбовці користуються усіма правами і свободами людини та громадянина, гарантіями цих прав і свобод, закріпленими в Конституції України та законах України й міжнародно-правових актах. Однак є певні прогалини щодо захисту осіб, що перебувають у складі добровольчих формувань.

Мета дослідження полягає у вивченні законодавства щодо соціального та правового захисту військовослужбовців України та осіб, що перебувають у складі добровольчих формувань.

Захист та збереження основних прав громадян своєї держави є основним завданням будь-якої правової держави. Не є винятком у цьому контексті і Україна. Захист прав та соціальний захист військовослужбовців на законодавчому рівні регулюється законами України «Про соціальний і правовий захист військовослужбовців та членів їх сімей», «Про Збройні сили України» , «Про пенсійне 
забезпечення осіб, звільнених з військової служби, та деяких інших осіб», «Про статус ветеранів війни, гарантії ї соціального захисту», «Про статус ветеранів військової служби, ветеранів органів внутрішніх справ, ветеранів Національної поліції і деяких інших осіб та їх соціальний захист» . Військовослужбовці водночас із загальним правовим статусом володіють спеціальним статусом, який не просто доповнює загальний, а й змінює (обмежує) його. Спеціальний статус визначається сукупністю передбачених як загальним, зокрема Конституцією, так і спеціальним (військовим) законодавством прав, свобод, обов'язків і відповідальності. Усі суб'єктивні права військовослужбовців аналогічно поділяються на загальні та військово-службові, тобто права, зумовлені проходженням військової служби. При цьому серед загальних прав можна виділити загальногромадянські (в тому числі і конституційні) суб'єктивні права, якими володіють військовослужбовці, як і всі інші громадяни, в силу конституційного принципу рівноправності, які встановлюються загальним законодавством, а також загальногромадянські об’єктивні права, які також встановлюються загальним законодавством, але реалізація яких військовослужбовцями має певні особливості, зумовлені специфікою військової служби.

Основні соціальні гарантії та права військовослужбовців як учасників відносин у сфері дотримання прав і свобод людини та громадянина зосередженні в Законі України «Про соціальний і правовий захист військовослужбовців та членів їх сімей». У законі регламентовані такі соціально важливі питання для військовослужбовців: забезпечення громадянських прав і свобод військовослужбовців; недоторканність військовослужбовців; основні права військовослужбовців, пов'язані з проходженням служби; грошове забезпечення військовослужбовців; продовольче, речове та інше забезпечення військовослужбовців; службовий час і час відпочинку військовослужбовців; право військовослужбовців на відпустки; порядок надання військовослужбовцям відпусток та відкликання з них; права військовослужбовців на охорону здоров'я та медичну допомогу тощо [4].

Розглянемо більш детально деякі із передбачених прав військовослужбовців. Військовослужбовцю гарантується недоторканність. Він не може бути арештований інакше як на підставі судового рішення. Крім того, військовослужбовець не може залучатися до завдань, не передбачених його службовими обов'язками. Використання військовослужбовців для виконання завдань, не пов'язаних з військовою службою, забороняється та тягне за собою відповідальність відповідно до закону. Військовослужбовці можуть залучатися до участі у ліквідації наслідків аварій, катастроф, стихійних лих та в інших окремих випадках лише за рішенням Верховної Ради України [5, с. 23].

Під час несення військової служби військовослужбовцям надається грошове утримання. Грошове забезпечення визначається залежно від посади, військового звання, тривалості, інтенсивності та умов військової служби, кваліфікації, наукового ступеня і вченого звання військовослужбовця. За військовослужбовцями, захопленими в полон, або заручниками, а також інтернованими в нейтральних державах або безвісно відсутніми, зберігається грошове та інші види забезпечення. Сім'ям зазначених військовослужбовців щомісячно виплачується грошове забезпечення, в тому числі додаткові та інші види грошового забезпечення, в розмірі, що встановлений військовослужбовцю на день захоплення його в полон або заручником, інтернування в нейтральних державах або безвісного зникнення. Дія цього пункту не поширюється на військовослужбовців, які добровільно здалися в полон. Також одним із голових аспектів державної підтримки військовослужбовців є право військовослужбовців на охорону здоров'я та медичну допомогу. Охорона здоров'я військовослужбовців забезпечується створенням сприятливих санітарно-гігієнічних умов проходження військової служби, побуту, а також системою заходів 3 обмеження дії небезпечних факторів військової служби з урахуванням її специфіки та екологічної обстановки, які здійснюються командирами (начальниками) у взаємодії з місцевими органами виконавчої влади та органами місцевого самоврядування [6, с. 32].

Також Закон України «Про соціальний і правовий захист військовослужбовців та членів їх сімей" регулює питання забезпечення прав і свобод, соціального і правового захисту військовослужбовців, членів їх сімей та обмеження деяких прав у зв'язку із виконанням ними обов'язків військової служби, а саме:

військовослужбовці мають право брати участь у виборах, бути обраними до рад всіх рівнів, брати участь у всеукраїнському і місцевих референдумах, проте вони не можуть бути членами будьяких політичних партій, організаційних рухів, організовувати і проводити страйки. Гарантується свобода совісті і право вільно задовольняти свої релігійні потреби, свобода наукової, технічної та художньої творчості. Військовослужбовці не можуть займатися підприємницькою діяльністю, але держава гарантує їм матеріальне та інше забезпечення у розмірах, що стимулюють зацікавленість у військовій службі (грошове, речове забезпечення тощо);

Закон визначає порядок реалізації права військовослужбовців на відпочинок (тривалість робочого дня і розподіл службового часу, порядок надання основних та додаткових відпусток, забез- 
печення безоплатної медичної допомоги та санаторно-курортного лікування і відпочинку);

Закон визначає порядок забезпечення військовослужбовців житловими приміщеннями (до отримання постійного житлового приміщення військовослужбовцям повинні надаватися службові житлові приміщення, військовослужбовцям виплачується грошова компенсація за тимчасовий піднайом (найом) житла);

Закон передбачає право на отримання освіти (військовослужбовцям дозволяється навчатися в інших навчальних закладах без відриву від служби в порядку, визначеному Положенням про проходження громадянами України військової служби у ЗС України) та право на безкоштовний проїзд військовослужбовця та членів його сім'ї у відпустку в межах України, при переведенні до нового місця служби, до місця проживання, а також при звільнені з військової служби.

Цей Закон передбачає пенсійне забезпечення військовослужбовців, встановлює, що час перебування громадян України на військовій службі зараховується до їх страхового стажу, стажу роботи за спеціальністю, а також до стажу державної служби. Варто відзначити, що правові норми, які стосуються прав військовослужбовців, питань соціального захисту, дублюються в інших законах, які регулюють порядок створення та діяльності військових формувань в Україні. Так, у Законі України «Про Збройні сили України» міститься ст. 16 «Соціальний і правовий захист військовослужбовців, членів їх сімей та працівників Збройних сил України», яка фактично дублює правові норми Закону України «Про соціальний і правовий захист військовослужбовців та членів їх сімей» [7].

На даний момент в законодавстві стосовно визначення правового статусу осіб, що перебували чи перебувають у складі добровольчих формувань, що були утворені або самоорганізувалися для захисту незалежності, суверенітету та територіальної цілісності України, є прогалини, які потребують законодавчого врегулювання.

У чинному законодавстві немає визначення поняття «доброволець», натомість використовується формулювання «особи, що перебували у складі добровольчих батальйонів». Конвенція про закони та звичаї сухопутної війни 1907 р. наголошує, що добровольчі загони в тих країнах, де вони складають армію чи є її частиною, розуміються під словом «армія» за умови, що вони мають відповідальну особу, якій підпорядковується особовий склад, мають характерні ознаки, відкрито носять зброю, дотримуються законів та звичаїв війни.

Законом України «Про внесення змін до Закону України «Про статус ветеранів війни, гарантії ïx соціального захисту» щодо статусу осіб, які захищали незалежність, суверенітет та територіальну цілісність України» було встановлено, що до осіб, які належать до учасників бойових дій, також належать особи, які були у складі добровольчих формувань, що були утворені або самоорганізувалися для захисту незалежності, суверенітету та територіальної цілісності України, брали безпосередню участь в антитерористичній операції, забезпеченні їі проведення, перебуваючи безпосередньо в районах антитерористичної операції у період її проведення, якщо такі добровольчі формування були включені до складу Збройних сил України, Міністерства внутрішніх справ України, Національної гвардії України та інших утворених відповідно до законів України військових формувань та правоохоронних органів [8].

Можна зробити висновок, що якщо добровільне формування не було включене до складу ЗСУ, Міністерства внутрішніх справ України, Національної гвардії України та інших утворених відповідно до законів України військових формувань та правоохоронних органів, то військовослужбовці такого формування не зможуть отримати статусу учасників бойових дій. Це, вочевидь, є великою проблемою для осіб, які перебували або перебувають у складі таких формувань.

3 огляду на це обласні ради на всій території України почали самостійно приймати рішення про визнання добровольців, які брали участь у бойових діях в зоні АТО, учасниками бойових дій та про надання їм пільг, передбачених Законом України «Про статус ветеранів війни, гарантії їх соціального захисту» .

Наприклад, 9 жовтня 2015 року Івано-Франківська обласна рада одностайно ухвалила рішення «Про статус бійців добровольчих батальйонів у зоні АТО на Сході України». Таке рішення передбачало визнання учасниками бойових дій бійців добровольчих батальйонів, які були створені або самоорганізувалися та брали участь в АТО, але не були включені до ЗСУ, МВС, Національної гвардії та інших офіційних військових формувань. Подібні рішення згодом приймалися Тернопільською, Хмельницькою, Одеською, Харківською та іншими обласними радами на території України. Натепер в Одеській області статус учасника бойових дій наданий 21 бійцю добровольчих формувань.

У зв'язку із очевидною прогалиною в законодавстві стосовно визнання добровольців, які брали участь у бойових діях, учасниками бойових дій виникла нагальна потреба у врегулюванні даного питання. Був прийнятий Закон «Про внесення змін до деяких законодавчих актів України щодо надання статусу та соціальних гарантій окремим особам із числа учасників антитерористичної операції». Він передбачає порядок визначення правового статусу осіб із числа добровольців, які брали безпосередню участь в антитерористичній операції, у забезпеченні її проведення, перебуваючи безпосередньо в районах антитерористичної опе- 
рації у період їі проведення, але не були включені до складу Збройних сил України, Міністерства внутрішніх справ України, Національної гвардії України та інших утворених відповідно до законів України військових формувань та правоохоронних органів. Прийняття відповідного закону дозволяє визначити правовий статус добровольців на національному рівні, а не на рівні обласних рад, як це робилося раніше.

Даний Закон передбачає визначення статусу осіб, які у складі добровольчих формувань брали участь у бойових діях під час проведення антитерористичної операції, порядку надання добровольцям статусу учасника бойових дій і статусу осіб, які стали інвалідами внаслідок поранення, контузії або каліцтва, отриманого у бойових діях під час проведення антитерористичної операції у складі добровольчих формувань. Закон також визначає соціальні гарантії осіб, які брали участь у бойових діях під час проведення антитерористичної операції у складі добровольчих формувань, соціальні гарантії членів сімей осіб, які загинули (зникли безвісти, визнані померлими) або померли внаслідок поранення, контузії чи каліцтва, одержаних у ході проведення антитерористичної операції у складі добровольчих формувань [9].

У законі визначені критерії, за якими особи відносяться до відповідної категорії осіб. Наприклад, визначено, що добровольці визнаються учасниками бойових дій у разі залучення їх до проведення антитерористичної операції на строк не менше ніж 30 календарних днів, у тому числі за сукупністю днів перебування в районах її проведення. Також визначено порядок та підстави для надання добровольцям статусу учасника бойових дій.

Що стосується соціальних гарантій особам, які брали участь у бойових діях під час проведення антитерористичної операції у складі добровольчих формувань, та соціальних гарантій членам сімей осіб, які загинули (зникли безвісти, визнані померлими) або померли внаслідок поранення, контузії чи каліцтва, одержаних у ході проведення антитерористичної операції у складі добровольчих формувань, то даним Законом передбачається надання таких прав і гарантій, як і військовослужбовцям Збройних сил України.

Так, відповідні особи у разі усунення вищезазначених прогалин в законодавстві згідно із Законом України «Про статус ветеранів війни, гарантії їх соціального захисту» могли б отримати досить широкий перелік пільг, соціальних послуг та допомог учасникам АТО (ООС) (понад двадцять) i у такий спосіб прирівнятися у правах із військовослужбовцями.

Отже, варто зазначити, що, попри нагальну потребу у врегулюванні питань щодо цивільно-правового та соціального захисту військовослужбовців та осіб, що перебувають у складі добровольчих формувань, законодавство місить певні недоліки. Досить значна кількість нормативних актів містить повторення відповідних норм. Також слід сказати про відсутність узгодженої системи термінології. Існує окрема проблема із визнанням добровольців особами, що були у складі добровольчих військових формувань і брали участь у бойових діях. Така тенденція є негативною як в соціальному, так і правовому контексті. Вирішення такого питання на регіональному рівні не призведе до суттєвого покращення ситуації.

\section{Jimepamypa}

1. Конституція України : Закон України від 28 червня 1996 р. № 254к/96-ВР / Верховна Рада України. Відомості Верховної Ради України. 1996. № 30. Ст. 141.

2. Пашинський В.Й., Свистільник I.А. Правове регулювання соціального i правового захисту військовослужбовців в Україні. Юридична наука. 2013. С. $102-110$.

3. Міжнародне гуманітарне право : навчальний посібник / за заг. ред. В.П. Базова. Київ : Варта, 2000. $176 \mathrm{c}$.

4. Про соціальний i правовий захист військовослужбовців та членів їх сімей : Закон України від 20.12.1991 року № 2011 .

5. Ситняківська С.М., Хливнюк М.Г. Соціальний та правовий захист військовослужбовців (social and legal protection of military men). Енциклопедія прав людини : соціально-педагогічний аспект : колективна монографія / кол. авт., за заг. ред. проф. Н.А. Сейко ; відп. ред. Н.П. Павлик. 2014.

6. Ситняківська С.М., Хливнюк М.Г. Соціальний та правовий захист військовослужбовців (social and legal protection of military men). Енциклопедія прав людини : соціально-педагогічний аспект : колективна монографія / кол. авт., за заг. ред. проф. Н.А. Сейко ; відп. ред. Н.П. Павлик. 2014.

7. Про соціальний і правовий захист військовослужбовців та членів їх сімей : Закон України від 20.12.1991 р. № 2011-XII. URL: https://zakon.rada. gov.ua/laws/show/2011-12.

8. Про внесення змін до деяких законодавчих актів України щодо надання статусу та соціальних гарантій окремим особам із числа учасників антитерористичної операції : проєкт Закону України від 19.09.2019 p. URL: https://w1.c1.rada.gov.ua/pls/ zweb2/webproc4_1?pf3511=66905.

9. Про статус ветеранів війни, гарантії їх соціального захисту : Закон України від 22 жовтня 1993 р. Відомості Верховної Ради. 1993. № 45. 


\section{Анотація}

Кривенко Ю. В. Військовослужбовець та доброволець: правовий і соціальний захист. - Стаття.

Правовий та соціальний захист населення - це базова функція правової і соціальної держави. Однак механізми такого захисту не можуть бути тотожними для всіх груп населення. Це визначається специфікою взаємозв'язку особистих, групових і громадських інтересів в кожному конкретному випадку. Серед соціальних груп суспільства особливе місце посідають військовослужбовці, а у нас до них додаються ще й добровольці, статус яких не визначено у законодавстві. Їхнє специфічне призначення - це служба інтересам всього суспільства і держави. Ця служба накладає низку істотних обмежень на їхній правовий статус і правове становище в суспільстві, що особливо важливо відзначити 3 урахуванням ведення військових дій на території нашої держави. Водночас законодавець не поширює цей статус на працівників підприємств, установ, організацій, які залучалися та брали безпосередню участь у забезпеченні проведення антитерористичної операції, а також на осіб, які добровільно забезпечували (або добровільно залучалися до забезпечення) проведення антитерористичної операції (зокрема, здійснювали волонтерську діяльність). Проблема правових гарантій реалізації прав і обов'язків військовослужбовців та осіб, які були у складі добровольчих формувань, була і залишається однією 3 найбільш важливих з огляду на ведення бойових дій на території нашої держави. Автор вважає за необхідне впорядкувати законодавство без повторення відповідних норм у правових актах різної юридичної сили та узгодити загальнотеоретичні поняття. Це дозволить уникнути багатьох проблем на практиці. Існує окрема проблема із визнанням добровольців особами, що були у складі добровольчих військових формувань і брали участь у бойових діях. Така тенденція є негативною як в соціальному, так і правовому контексті.
Ключові слова: військовослужбовець, доброволець, учасник бойових дій, соціальний захист, правовий захист.

\section{Summary}

Kryvenko Yu.V. Serviceman and volunteer legal and social protection. - Article.

Legal and social protection of the population is the basic function of a legal, social state. However, mechanisms such protection can't be identical for all groups of population without exception. This is determined by the specific relationship of personal, group and public interests in each case. Among the social groups of society, a special place is occupied by servicemen, and to them are added volunteers whose status is not defined. Their specific purpose is to serve the interests of the entire society and the state. This service imposes a number of significant restrictions on their legal status and legal status in society, which is especially important to note given the conduct of hostilities in the territory of our country. At the same time, the legislator does not extend this status to employees of enterprises, institutions, organizations involved and directly involved in providing anti-terrorist operations, as well as persons who voluntarily provided (or voluntarily involved in providing) anti-terrorist operations (including volunteering activity). The problem of legal guarantees of the rights and duties of military personnel and persons, which were part of the volunteer units, was and remains one of the most important, given the conduct of hostilities on the territory of the state. The author considers is necessary to streamline legislation without repeating the relevant norms, in legal acts of different legal force and agree on general theoretical concepts which will avoid a number of problems in practice. There is a particular problem with the recognition of volunteers as volunteers who participated in hostilities. This tendency is negative both socially and legally.

Key words: serviceman, volunteer, combatant, social protection, legal protection. 